Jurnal Teknologi Laboratorium

Vol.9, No.2, 2020, pp. $151-158$

ISSN 2580-0191(Online), ISSN 2338 - 5634(Print)

DOI: 10.29238/teknolabjournal.v9i2.213

Journal homepage: https://www.teknolabjournal.com/index.php/Jt//index

Original Research.

OPEn 6 Access

\title{
Erythrocyte index of residents exposed to lead in Tambaklorok, Semarang, Indonesia
}

\section{Budi Santosa $^{a^{*}}$, Herlisa Anggraini ${ }^{b}$, Ika Dyah Mawarni $^{\mathrm{c}}$, Niza Muliatun ${ }^{\mathrm{d}}$, Ardiansyah Nugroho ${ }^{\mathrm{e}}$, Uly Syarah', Siti Atika Risqoeni ${ }^{\mathrm{g}}$}

Department of Medical Laboratory Technology, Universitas Muhammadiyah Semarang, Semarang, Indonesia

aE-mail address: budisantosa@unimus.ac.id

bE-mail address: herlisa@unimus.ac.id

cE-mail address: ikadyah1708@gmail.com

dE-mail address: nizamuliatun42@gmail.com

eEmail address: nugrohoardi768@gmail.com

'Email address: ulysarah19@gmail.com

9Email address: atikarisqoeni1305@gmail.com

\section{HIGHLIGHTS}

The erythrocyte index value was mostly in the normal category

\section{ARTICLE INFO}

\section{Article history}

Received Date: March 03, 2020

Revised Date: Aug 18, 2020

Accepted Date: Aug 26, 2020

\section{Keywords:}

Classification of types of anemia

Erythrocyte index

peripheral blood smear preparation

\begin{abstract}
A B S T R A C T
Erythrocyte index can form erythrocyte morphology in the peripheral blood smear preparation. Lead exposure in Tambaklorok exceeds the threshold that affects anemia. The purpose of this study was to determine the erythrocyte index confirmation with erythrocyte morphology in the peripheral blood smear preparation. A cross-sectional study was conducted in 2month in Tambaklorok Semarang residents and 104 samples were taken using the purposive technique. Erythrocyte index was measured using the hematological analyzer and erythrocyte morphology in the peripheral blood smear preparation using Giemsa painting. Erythrocyte index confirmation with the peripheral blood smear preparation was analyzed using the Gamma statistical relationship test. The results showed that the erythrocyte index value was mostly in the normal category, i.e., MCH 68 (64.4\%), MCHC 61 (58.6\%) and $\mathrm{MCH} 58$ $(56 \%)$ and below normal category were $\mathrm{MCH} 45$ (42.95\%), MCHC 41 (39.4\%), and MCV 36 (34.3\%). Erythrocyte morphology was mostly hypochromic, namely 46 (44.23\%), normochrome 40 (38.46\%), and hyperchrome 18 (17.3\%). Relationship of $\mathrm{MCH}$ with erythrocyte color $\mathrm{p}$ value 0.037 with size $p$-value 0.038 . Conclusion of erythrocyte index confirmation, especially $\mathrm{MCH}$ with the peripheral blood smear preparation, there was a match on the color and size of erythrocytes, while the MCV and $\mathrm{MCHC}$ values had no significant relationship.
\end{abstract}

This is an open-access article under the CC-BY-SA license.

\section{*Corresponding Author: \\ Budi Santosa}

Master of Science Medical Laboratory, Universitas Muhammadiyah Semarang

Jl. Kedungmundu Raya 18 Semarang

Email: budisantosa@unimus.ac.id 


\section{INTRODUCTION}

Erythrocyte index was determined by calculating three parameters, namely hemoglobin $(\mathrm{Hb})$, hematocrit $(\mathrm{Ht})$ levels, and the number of Erythrocytes. Erythrocyte index calculation results show the average volume of erythrocytes and the average hemoglobin per erythrocyte, the average concentration of hemoglobin per erythrocyte. Clinically examination of the erythrocyte index is used as a filter for diagnosing anemia and its classification based on erythrocyte morphology. ${ }^{-}$Measurement of erythrocyte index needs to be confirmed using erythrocyte morphology examination on the peripheral blood smear preparation.?

Erythrocyte index consists of mean corpuscular volume (MCV), mean corpuscular hemoglobin $(\mathrm{MCH})$, mean corpuscular hemoglobin concentration $(\mathrm{MCHC})$. MCV is measured by comparing $\mathrm{Ht}$ levels with the number of erythrocytes in million / ul multiplied by 10 in femtoliter units ( $\mathrm{fl}), \mathrm{MCH}$ is measured by comparing $\mathrm{Hb}$ levels with the number of erythrocytes in million / ul multiplied by 10 by picogram units $(\mathrm{pg}), \mathrm{MCHC}$ is measured by comparing $\mathrm{Hb}$ levels with $\mathrm{Ht}$ multiplied by $100 \%$. MCV reference values $82-92 \mathrm{fl}, \mathrm{MCH} 27-31 \mathrm{pg}$, and $\mathrm{MCHC}$ 30-35 gr / dl. .3

Peripheral blood smear preparation is a strategy to see the morphology of blood cells including erythrocytes, leukocytes, and thrombocytes. ${ }^{4}$ Erythrocyte morphology is examined based on size, color, shape, and inclusion. High MCV and $\mathrm{MCH}$ will give an overview of the size of erythrocytes in peripheral blood smear preparation enlarge (macrocytes) and otherwise if the MCV and $\mathrm{MCH}$ are low, then the size of erythrocytes in peripheral blood smear preparation becomes smaller (microcytes). $\frac{3}{-}$ It is important to know how the erythrocyte morphology in peripheral blood smear preparation is useful for confirming the erythrocyte index.

Increased MCV is found in aplastic anemia, hemolytic anemia, pernicious anemia, folic acid deficiency anemia, while decreased MCV is found in microcytic anemia, iron deficiency anemia, thalassemia, sickle cell anemia, lead/ plumbum poisoning.., 3

Lead exposure can cause anemia through the Delta-aminolevulinic acid dehydratase (ALAD) enzyme inhibition pathway in the heme biosynthesis process and has been proven, $\underline{6}$ but the erythrocyte index is not yet known with confirmation of peripheral blood smear preparation so that anemia is known. The benefits of anemia classification are very useful in the process of managing patients with anemia.

Various causes of anemia include lead exposure either through inhalation, digestion, or skin. ${ }^{7}$ Lead that enters the body will accumulate and cause detoxification in both liver and kidney detoxification organs. ${ }^{8}, \underline{9}$ Biochemically erythropoietin hormone which functions for erythropoiesis is disrupted so that the formation of erythrocytes is inhibited. Lead can also inhibit the ALAD delta enzyme in the process of heme synthesis, so that heme is not formed which results in decreased levels of hemoglobin in the blood and the volume of erythrocytes becomes abnormal as indicated by a decrease in hematocrit levels. These parameters are used to determine the erythrocyte index.

Tambaklorok is part of the city of Semarang which is located in the northern part close to the north coast. Currently, the Tambaklorok region is a densely populated and industrious area. Various industries that have the potential as sources of lead contamination are the textile, pharmaceutical, power plant, ship repair, paint industry, cosmetics, batteries, pipes, ceramic coatings, children's toys, and others ${ }^{10}$ located in Tambaklorok. Industrial waste management is not all good, a lot of industrial waste before going through the treatment process is discharged through the flow of water up to the edge of the sea resulting in polluted marine commodities such as green shells, seaweed, and fish consumed by many Tambaklorok residents. According to research conducted by Supriyantini and Soenardjo 2015, waters around Tanjung Emas including Tambaklorok area found to contain a lead level of 0.06 $\mathrm{ppm}$, while the maximum standard quality was $0.008 \mathrm{ppm} . \stackrel{11}{ }$ Other research conducted by $\mathrm{Tm}$ NK 2011, showed Pb levels that polluted the air in Tambaklorok region was $8.41 \mu \mathrm{g} / \mathrm{m} 3$ above the threshold value of quality $2 \mu \mathrm{g} / \mathrm{m} 3$ per 24 hours, the highest compared to other regions in the city of Semarang. $\frac{12}{2}$ Results of research conducted by Marianti A. Prasetya AT, 2013, lead content in hair of North Semarang residents showed that 56 residents had the highest lead content of $17,028 \mathrm{ppm}$ and an average of $8,304 \mathrm{ppm}$. The cause is thought to 
originate from drinking water consumed by the residents containing an average lead level of

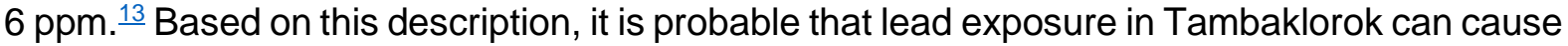
anemia. Therefore the classification of anemia based on the erythrocyte index becomes important to know so that the handling of anemia due to lead exposure can be overcome.

\section{MATERIAL AND METHOD}

This type of analytic research is a cross-sectional approach, study from January to March 2020. The study population is the residents of Tambaklorok Semarang and the number of samples is 104 taken based on the Lemeshow formula. ${ }^{14}$ Sampling uses a purposive technique by not limiting age groups to residents who have lived for at least five years. Lead content data from Tambaklorok residents in the form of secondary data were obtained from the study of Marianti A, Prasetya AT, 2013. The erythrocyte index was obtained from measurements of venous blood samples using a hematology analyzer with the impedance principle. Erythrocyte morphology in the form of erythrocyte size and color was identified using peripheral blood smear preparation with Giemsa staining. To confirm the erythrocyte index with erythrocyte morphology in the peripheral blood smear preparation, a relationship test was performed using the Gommer test.

The study was conducted after obtaining ethical clearance from the Medical Faculty of UNISULA Semarang No.064/II/2020/Komisi/Bioetik. The Head of the Clinical Pathology Laboratory of the University of Muhammadiyah Semarang agreed to research after receiving notification of the results of ethical clearance. Erythrocyte index examination and erythrocyte morphology was carried out in the clinical pathology laboratory of Unimus.

\section{RESULTS AND DISCUSSION}

Erythrocyte index examination in the form of $\mathrm{MCV}, \mathrm{MCH}, \mathrm{MCHC}$ as well as a morphological description of erythrocytes based on color and size was carried out on Tambaklorok residents of Semarang who were suspected of being exposed to lead. MCV, $\mathrm{MCH}, \mathrm{MCHC}$ values can be seen in figure 1. The graphs of increase and decrease in MCV, $\mathrm{MCH}, \mathrm{MCHC}$ in each sample are almost the same. If there is an increase in MCV will be followed by an increase in $\mathrm{MCH}$ and $\mathrm{MCHC}$ and vice versa, although the increase or decrease can not be measured with the same number. It can be explained that each increased erythrocyte volume will be followed by a decrease in the mean and the percentage of hemoglobin levels. Likewise, a decrease in erythrocyte volume will be followed by a decrease in the mean and percentage of hemoglobin levels.

The mean value of MCV is still in the normal category even though it is at the lowest limit of its normal value (83.1), so is the mean value of MCHC that is also at the lowest limit of its normal value of 32. Whereas the mean value of $\mathrm{MCH}$ is below normal (26.8) (Table 1). The erythrocyte index value is mostly normal (Table 2), the highest normal category is MCH 68 (64.4\%), followed by MCHC 61 (58.6\%) and MCH 58 (56\%). The highest erythrocyte index values below normal were MCH 45 (42.95\%), MCHC 41 (39.4\%), and MCV 36 (34.3\%).

Table 1. Average MCV, $\mathrm{MCH}, \mathrm{MCHC}$ among Tambaklorok residents in Semarang

\begin{tabular}{cccccc}
\hline Variable & $\mathrm{n}$ & Average & SD & Highest & Lowest \\
\hline MCV & 104 & 83.2 & 4.99 & 84.20 & 82.30 \\
MCH & 104 & 26.8 & 1.99 & 27.20 & 26.40 \\
MCHC & 104 & 32.0 & 3.40 & 32.30 & 31.30 \\
\hline
\end{tabular}

Table 2. Values of $\mathrm{MCV}, \mathrm{MCH}$, and $\mathrm{MCHC}$ based on normal values

\begin{tabular}{ccccc}
\hline Variable & $\mathrm{N}$ & \multicolumn{3}{c}{ Results } \\
\cline { 3 - 5 } & & $\begin{array}{c}<\text { Normal } \\
(\%)\end{array}$ & $\begin{array}{c}\text { Normal } \\
(\%)\end{array}$ & $\begin{array}{c}>\text { Normal } \\
(\%)\end{array}$ \\
\hline $\mathrm{MCV}$ & 104 & $36(34.30)$ & $68(64.40)$ & $1(1.00)$ \\
$\mathrm{MCH}$ & 104 & $45(42.90)$ & $58(56.00)$ & $1(1.00)$ \\
$\mathrm{MCHC}$ & 104 & $41(39.40)$ & $61(58.60)$ & $2(1.90)$ \\
\hline
\end{tabular}


In the peripheral blood smear preparation that has been stained with Giemsa staining, erythrocyte morphology can be grouped into hypochromic, that is, pale color with a diameter exceeding $1 / 3$ central polar, normochromic that is normal with a pale color $1 / 3$ the diameter of the central polar, and hyperchromic that is pale the entire surface of the erythrocyte does not appear to have a central poll. Besides being grouped by color, the morphology of erythrocytes is also seen based on their size, which is normal (normocyte), which is $6.9 \mu$ and $9.6 \mu$., Small (microcytes), and large (macrocytes). The following in figure 2 an example of hypochromic normocytic erythrocyte morphology.

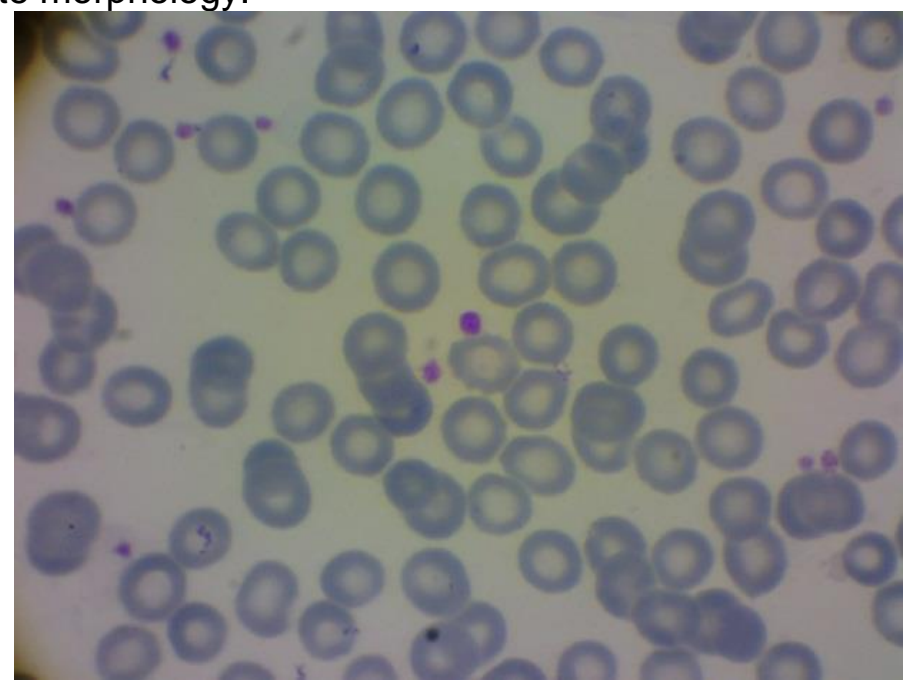

Figure 2. Hypochromic Normocytic

In Figure 2, it comes from sample no. 50 whose $\mathrm{MCV}$ value is $87.7 \mathrm{fl}$ and $\mathrm{MCH}$ is $26.6 \mathrm{pg}$

The morphology of erythrocytes (Table 3 ) based on color abnormalities was mostly found hypochromic, namely 46 samples (44.23\%), while normochrome 40 samples $(38.46 \%)$, and the least hyper chrome was 18 (17.3\%). Erythrocyte morphology (Table 4) based on size abnormalities, found 72 (69.23 samples of normal size (normocytic), only 14 (13.46\%) were microcytic, and 18 (17.3\%) were macrocytic.

Table 3. Erythrocyte morphology based on color abnormalities

\begin{tabular}{ccc}
\hline Color & Frequency & $\begin{array}{c}\text { Percentage } \\
(\%)\end{array}$ \\
\hline Hypochromic & 46 & 44.23 \\
Normochromic & 40 & 38.46 \\
Hyperchromic & 18 & 17.30 \\
\hline Total & 104 & 100 \\
\hline
\end{tabular}

Table 4. Erythrocyte morphology based on the size of the measurement

\begin{tabular}{ccc}
\hline Size & Frequency & $\begin{array}{c}\text { Percentage } \\
(\%)\end{array}$ \\
\hline Microcytic & 14 & 13.46 \\
Normocytic & 72 & 69.23 \\
Macrocytic & 18 & 17.30 \\
\hline Total & 104 & 100 \\
\hline
\end{tabular}

$\underline{\text { Tables } 5}$ and $\underline{6}$ are a recap of the results of statistical tests of the relationship between the erythrocyte index and the morphology of erythrocytes based on the color and size of the erythrocytes. Based on the results of the gamma statistical test, only $\mathrm{MCH}$ with color and $\mathrm{MCH}$ with a size that has a relationship, respectively, the $p$-value is 0.038 and 0.037 . MCV and $\mathrm{MCHC}$ both in color and size are statistically not significant. 
Table 5. Erythrocyte index based on the color of erythrocytes in the peripheral blood smear preparation

\begin{tabular}{cccccc}
\hline \multirow{2}{*}{$\begin{array}{c}\text { Erythrocyte } \\
\text { index }\end{array}$} & Category & Hypochromic & Normochrome & Hyperchrome & P-value \\
\cline { 3 - 5 } MCV & $<\mathrm{N}$ & 17 & 12 & 7 & \\
& $\mathrm{~N}$ & 28 & 28 & 11 & 0.783 \\
& $>\mathrm{N}$ & 0 & 1 & 0 & \\
\hline $\mathrm{MCH}$ & $<\mathrm{N}$ & 25 & 14 & 6 & \multirow{2}{*}{0.038} \\
& $\mathrm{~N}$ & 20 & 26 & 12 & \\
\hline $\mathrm{MCHC}$ & $>\mathrm{N}$ & 0 & 1 & 0 & \\
& $<\mathrm{N}$ & 19 & 10 & 12 & \multirow{2}{*}{0.587} \\
& $\mathrm{~N}$ & 26 & 29 & 6 & \\
\hline
\end{tabular}

Table 6. Erythrocyte index based on the size of erythrocytes in the Peripheral Blood Smear

\begin{tabular}{|c|c|c|c|c|c|}
\hline \multirow{3}{*}{ Erythrocyte index } & & Prepara & & & \multirow{3}{*}{$\begin{array}{c}\mathrm{P}- \\
\text { value }\end{array}$} \\
\hline & \multirow[t]{2}{*}{ Category } & \multicolumn{3}{|c|}{ Size } & \\
\hline & & Microcytic & Normocytic & Macrocytic & \\
\hline \multirow[t]{3}{*}{ MCV } & $<N$ & 6 & 24 & 6 & \\
\hline & $\mathrm{N}$ & 7 & 48 & 12 & 0.632 \\
\hline & $>\mathrm{N}$ & 0 & 1 & 0 & \\
\hline \multirow[t]{3}{*}{$\mathrm{MCH}$} & $<\mathrm{N}$ & 9 & 31 & 5 & \\
\hline & $\mathrm{N}$ & 4 & 41 & 13 & 0.037 \\
\hline & $>\mathrm{N}$ & 0 & 1 & 0 & \\
\hline \multirow[t]{3}{*}{$\mathrm{MCHC}$} & $<\mathrm{N}$ & 3 & 35 & 3 & \\
\hline & $\mathrm{N}$ & 10 & 36 & 15 & 0.516 \\
\hline & $>\mathrm{N}$ & 14 & 73 & 18 & \\
\hline
\end{tabular}

Based on the results of the study it was found that the average value of $\mathrm{MCH}$ was in the lowest normal limit and most were less than normal when compared with MCV and MCHC. The statistical test results obtained a p-value of 0.038 between $\mathrm{MCH}$ and erythrocyte color and size, meaning that there is a significant relationship between $\mathrm{MCH}$ and erythrocyte color and erythrocyte size. $\mathrm{MCH}$ is the average level of hemoglobin contained in erythrocytes. The higher the level of hemoglobin in the blood, the higher the hemoglobin content in erythrocytes will be and vice versa so that it can be used as an indicator of anemia. $\frac{3,15}{15}$ Such a condition, when viewed in terms of erythrocyte morphology in the preparation of peripheral blood smear, will give a picture of pale erythrocytes. The pale color is determined by the width of the central polar diameter of the erythrocytes. The pale coloration of erythrocytes in peripheral blood smear preparations is increasingly apparent with Giemsa staining..$\underline{16}$

In this study, $\mathrm{MCH}$ with erythrocyte size was also found to have a significant relationship. Some studies of erythrocyte size are related to erythrocyte volume. $\frac{15}{}$ In this study showed that the hemoglobin content was also related to the volume of erythrocytes. If the hemoglobin content in erythrocytes decreases, the size of erythrocytes also decreases. $\frac{17}{17}$ Several studies have shown that the color and size of erythrocytes were associated with the type of anemia. A decrease in $\mathrm{MCH}$ occurs in patients with microcytic anemia and hypochromic anemia, whereas an increase in $\mathrm{MCH}$ occurs in patients with iron deficiency anemia. $\underline{18,19}, \underline{20}$

Hypochromic anemia based on the results of this study occurred due to low hemoglobin levels in the samples/ respondents. The low level of hemoglobin of Tambaklorok Semarang residents was inseparable from the previous history of lead exposure that was above the threshold. Hemoglobin is composed of heme and globin, the presence of lead can

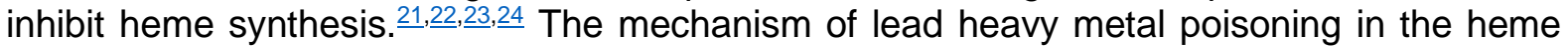
synthesis process occurs as a result of suppressing enzyme activity at the beginning, middle, and end of heme biosynthesis. Enzyme $\delta$ ALAD is a starting enzyme that is inhibited by the presence of lead. Due to the inhibition of lead in the $\delta$ ALAD enzyme, it will cause the cessation of $\delta$ ALA to become porphobilinogen (PBG). This can result in increased levels of ALA in the 
blood and urine. The intermediate enzyme that is inhibited by lead exposure is coproporphyrinogen oxidase which can cause an increase in coproporphyrinogen levels. The last enzyme that is inhibited by lead in the heme biosynthesis process is ferrochelatase. Obstacles that occur in ferrochelatase will cause elevated levels of protoporphyrin in red blood cells / free erythrocyte protoporphyrin (EPP) so that the porphyrin ring is not formed and results in the failure of heme formation. $\underline{25,26}$

The results of statistical tests for MCV and MCHC values obtained an average $p$-value above 0.05 , which means that statistically there is no significant relationship with the size and color of erythrocytes, although descriptively there is a downward trend in the mean value. This could be possible through hematocrit levels and the number of erythrocytes was decreasing, some were still within normal limits. The main finding of this study is that erythrocyte morphology in peripheral blood smear preparation can be used as confirmation of erythrocyte index results, although the strength of this study is only significant in the relationship of $\mathrm{MCH}$ to erythrocyte color and size. The limitation of this study is that in a population with mild anemia, further research is needed to confirm the erythrocyte index based on erythrocyte morphology in peripheral blood smear preparation preparations in a severe anemia population.

\section{CONCLUSION}

Based on the results of research and discussion it can be concluded that the erythrocyte index confirmation, especially $\mathrm{MCH}$ with the morphology of erythrocytes in the form of color and size is appropriate as evidenced by a significant relationship, while the values of MCV and MCHC have no significant relationship.

\section{DISCLOSURE STATEMENT}

The authors declare that they have no conflict of interest.

\section{ACKNOWLEDGEMENT}

The acknowledgment was given to the Medical Laboratory Technology Study Program, Faculty of Nursing, and Health Sciences who have been willing to provide research facilities.

\section{FUNDING INFORMATION}

The authors declared that this case has received no financial support.

\section{REFERENCES}

1. Budiwiyono $\mathrm{Y}$, Rachmawati $\mathrm{B}$, Hendrianingtyas $\mathrm{M}$. Perbedaan index eritrosit pada pasien anemia gagal ginjal kronik dan thalassemia mayor. $J$ Kedokt Diponegoro. 5(4):1911-22.

2. Daulay MCG. Morfologi Eritrosit Pada Sediaan Apus Darah Tepi (SADT) Sampel Dengan Hasil Pemeriksaan One Tube Osmotic Fragility Test (OTOFT) Positif. Skripsi. 2013;1`12.

3. Sarma PR. Red Cell Indices. Vol 30.; 1990. http://www.ncbi.nlm.nih.gov/pubmed/21250103.

4. Rubiyanti A. Morfologi eritrosit pada penderita anemia defisiensi besi metode apusan darah tepi.

5. Salim Y, Sukartini N, Setiawati A. Erythrocyte Indices to Differentiate Iron Deficiency Anemia from B Trait Thalassemia (Indeks Eritrosit untuk Membedakan Anemia Defisiensi Besi dengan Thalassemia $\beta$ Trait). Indones $J$ Clin Pathol Med Lab. 2018;23(1):50. doi:10.24293/ijcpml.v23i1.1184.

6. Chiu Y-W, Liu T-Y, Chuang H-Y. The Effects of Lead Exposure on the Activities of $\delta$-Aminolevulinic Acid Dehydratase with the Modification of the Relative Genotypes. Pirrone N, ed. E3S Web Conf. 2013;1:26005. doi:10.1051/e3sconf/20130126005. 
7. Hsieh $\mathrm{N}-\mathrm{H}$, Chung $\mathrm{S}-\mathrm{H}$, Chen $\mathrm{S}-\mathrm{C}$, et al. Anemia risk in relation to lead exposure in lead-related manufacturing. BMC Public Health. 2017;17(1):389. doi:10.1186/s12889-017-4315-7.

8. Santosa B, Iswara A, Ernanto AR. IR-bagendit leaves water extract as preventing agent in hematopoiesis, degeneration and necrosis in kidney tubulus of lead-exposed rats. Pakistan J Med Heal Sci. 13(3):899-904.

9. Multipalli A. Lead hepatotoxicity \& potential health effects. Indian J Med Res. 126(6):518-27.

10. Branch C. Study on the possible effects on human health and the environment in Asia and the Pacific of the trade of products containing lead, cadmium and mercury. In: UNITED NATIONS ENVIRONMENT PROGRAMME CHEMICALS BRANCH.

https://ipen.org/sites/default/files/documents/health effects heavy metals asi a pacific-en.pdf.

11. Supriyantini E, Soenardjo N. Kandungan logam berat timbal (Pb) dan tembaga (Cu) pada akar dan buah Mangrove Avicennia marina di perairan Tanjung Emas Semarang. J Kelaut Trop. 2016;18(2):98-106. doi:10.14710/jkt.v18i2.520.

12. Nana Kariada. Tingkat Kualitas Udara Di Jalan Protokol Kota Semarang. J Sains dan Teknol. 2011;9(2):111-20. doi:10.15294/sainteknol.v9i2.5532.

13. Marianti A, Prasetya AT. Rambut Sebagai Bioindikator Pencemaran Timbal Pada Penduduk Di Kecamatan Semarang Utara. Biosaintifika J Biol Biol Educ. 2013;5(1):10-5. doi:https://doi.org/10.15294/biosaintifika.v5i1.2568.

14. Lemeshow S, David W. Jr K, J. Adequacy of Sample Size in Health Studies. :41-57.

https://www.academia.edu/39511442/Adequacy of Sample Size in Health Studies.

15. Khanam S, Begum N, Hoque AE. Relationship of Hemoglobin, Packed Cell Volume and Total Count of RBC with the Severity of Chronic Renal Failure. Chattagram Maa-O-Shishu Hosp Med Coll J. 2013;12(2). doi:10.11566/cmoshmcj.v12i2.36.

16. Adewoyin AS, Nwogoh B. Peripheral blood film - a review. Ann Ibadan Postgrad Med. 2014;12(2):71-79. http://www.ncbi.nlm.nih.gov/pubmed/25960697.

17. Malka R, Delgado FF, Manalis SR, Higgins JM. In Vivo volume and hemoglobin dynamics of human red blood cells. Beard DA, ed. PLoS Comput Biol. 2014;10(10):e1003839. doi:10.1371/journal.pcbi.1003839.

18. Otto JM, Plumb JOM, Clissold E, et al. Hemoglobin concentration, total hemoglobin mass and plasma volume in patients: implications for anemia. Haematologica. 2017;102(9):1477-1485. doi:10.3324/haematol.2017.169680.

19. Buttarello M. Laboratory diagnosis of anemia: are the old and new red cell parameters useful in classification and treatment, how? Int $J$ Lab Hematol. 2016;38:123-132. doi:10.1111/ijlh.12500.

20. Singh M, Gautam A. To evaluate anaemia by erythrocyte indices, red cell distribution width and haemoglobin electrophoresis with special reference to thalassemia in paediatric age group. J Evol Med Dent Sci. 2015;04(11):17551764. doi:10.14260/jemds/2015/251.

21. Ogun AS, Joy N V., Valentine M. Biochemistry, Heme Synthesis.; 2020. https://www.ncbi.nlm.nih.gov/books/NBK537329/.

22. Santosa B. Variasi dosis suplementasi $\mathrm{Zn}$ memperbaiki hematopoesis pada tikus yang terpajan Plumbum (Pb). :37-45.

23. Santosa B, Sunoko HR, Sukeksi A. Aqueous IR Bagendit rice leaf extract 
decreases reticulocyte count in lead-exposed rats. Universa Med. 2018;37(1):57. doi:10.18051/UnivMed.2018.v37.57-64.

24. Santoso B, Subagio HW, Suromo L, Sunomo HR. Zinc supplementation improves heme biosynthesis in rats exposed to lead. Universa Med. 2016;34(1):3. doi:10.18051/UnivMed.2015.v34.3-9.

25. Agency for Toxic Substances and Disease Registry (ATSDR). Lead Toxicity Case Studies in Environmental Medicine. WB2832:1-182. https://www.atsdr.cdc.gov/csem/lead/docs/CSEM-Lead toxicity 508.pdf.

26. Sassa S. Toxic Effects of Lead, with Particular Reference to Porphyrin and Heme Metabolism. In: Heme and Hemoproteins. Berlin, Heidelberg: Springer Berlin Heidelberg; 1978:333-371. doi:10.1007/978-3-642-66763-3 11.

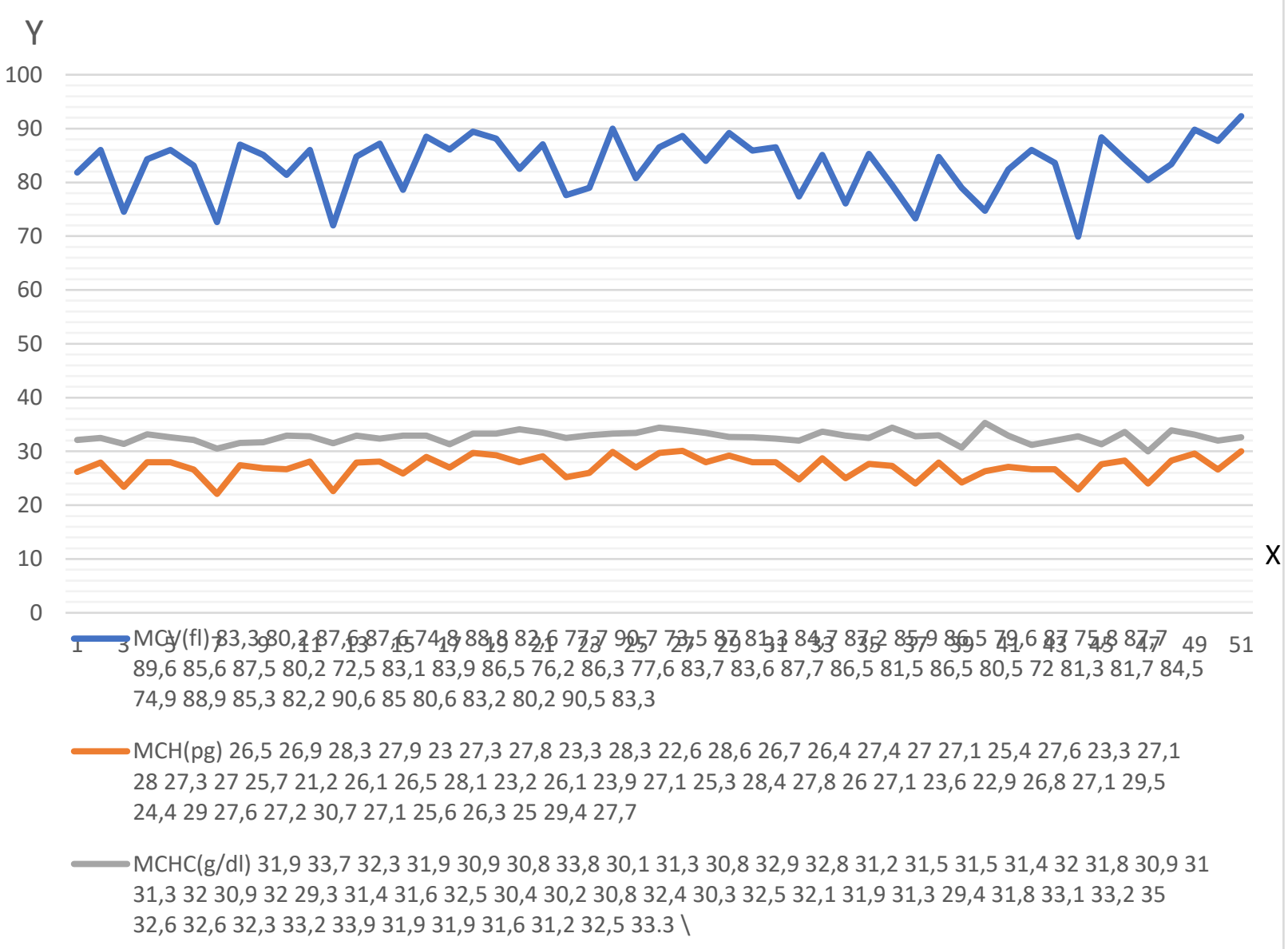

Figure 1. Distribution of MCV, MCH, MCHC values in Respondents ( $\mathrm{Y}=\mathrm{MCV}, \mathrm{MCH}, \mathrm{MCHC} . \mathrm{X}=$ no sample) 